\title{
IMPLEMENTASI E-LEARNING UNTUK MENINGKATKAN PARTISIPASI SISWA DALAM PEMBELAJARAN SEHINGGA LEBIH INTERAKTIF DAN MENYENANGKAN
}

\author{
Muhammad Ruslan Maulani ${ }^{1}$, Supriady $^{2}$, Noviana Riza ${ }^{3}$ \\ Teknik Informatika \\ Politeknik Pos Indonesia \\ Jl. Sariasih No. 54, Kota Bandung \\ ruslanmaulani@poltekpos.ac.id ${ }^{1}$, yadi.ipchi@gmail.com² ${ }^{2}$, novianariza@poltekpos.ac.id
}

\begin{abstract}
Abstrak
Menurut UUD 1945, Sekolah Dasar merupakan suatu upaya untuk mencerdaskan dan mencentak kehidupan bangsa yang bertaqwa, cinta dan bangga terhadap bangsa dan negara, terampil, kreatif, berbudi pekerti, dan santun serta mampu menyelesaikan permasalahan dilingkungannya. Salah satu cara untuk mencapai tujuan tersebut yaitu dengan menerapkan metode pembelajaran siswa secara daring atau dikenal juga sebagai pembelajaran e-Learning. Penggunaan ELearning dilakukan dengan memanfaatkan teknologi informasi dan komunikasi. Sistem pembelajaran dilaksanakan melalui perangkat komputer atau laptop yang terhubung dengan koneksi internet. Namun, dalam pelaksanaanya proses pembelajaran menggunakan e-Learning masih dirasa kurang interaktif dan beberapa siswa merasa jenuh. Oleh karena itu, peneliti bertujuan untuk mengimplementasikan e-Learning sebagai media pembelajaran yang dapat meningkatkan partisipasi siswa dalam pembelajaran sehingga lebih interaktif dan menyenangkan. Metode yang digunakan yaitu model waterfall yang telah dikembangkan oleh Sommerville. Tetapi, penulis mengembangkan model waterfall tersebut sesuai dengan kebutuhan penelitian yaitu tahap persiapan (rumusan masalah dan tujuan penelitian, studi literatur, pengumpulan data), tahap analisis dan perancangan (analisis system, analisis kebutuhan, perancangan), tahap implementasi dan pengujian (implementasi, pengujian black box dan pengujian aspek pengguna) serta tahap pelaporan. Adapun hasil dari peneletian ini yaitu sistem pembelajaran daring yang mengimplementasikan elearning dengan menggunakan konsep CCAF (Context, Challenge, Activity and Feedback) dan Learning Games.
\end{abstract}

Kata kunci : E-Learning, CCAF, Learning Games

\begin{abstract}
According to the 1945 Constitution, Elementary School is an effort to educate and enlighten the life of a nation that is devout, loves, and proud of the nation and state, is skilled, creative, ethical, and polite, and can solve problems in its environment. One way to achieve this goal is by applying online student learning methods, also known as e-Learning. The use of E-Learning is carried out by utilizing information and communication technology. The learning system is implemented through a computer or laptop connected to an internet connection. However, in its implementation, the learning process using eLearning is still not interactive and some students feel bored. Therefore, researchers aim to implement $e$ Learning as a learning medium that can increase student participation in learning so that it is more interactive and fun. The method used is the waterfall model that has been developed by Sommerville. However, the authors developed the waterfall model following the research needs, namely the preparation stage (problem formulation and research objectives, literature study, data collection), analysis and design (system analysis, needs analysis, design), implementation, and testing (implementation, testing). black box and testing user aspects) as well as the reporting stage. The results of this research are an online learning system that implements e-learning using the concept of CCAF (Context, Challenge, Activity, and Feedback) and Learning Games.
\end{abstract}

Keywords : E-Learning, CCAF, Learning Games 


\section{Pendahuluan}

Perkembangan teknologi informasi beberapa tahun belakangan ini berkembang dengan cepat, sehingga dengan perkembangan ini telah mengubah paradigma masyarakat dalam mencari dan mendapatkan informasi yang tidak lagi terbatas pada informasi surat kabar dan elektroniik saja, tetapi juga sumber-sumber informasi lainnya yang salah satunya adalah dengan menggunakan internet.

Salah satu bidang yang mendapatkan dampak yang berarti dengan perkembangan teknologi ini adalah bidang pendidikan, dimana pada dasarnya pendidikan merupakan suatu proses komunikasi dan informasi dari pendidik ke peserta didik yang berisi informasi-informasi pendidikan, yang memiliki unsurunsur pendidik sebagai sumber informasi, media sebagai sarana penyajian ide dan gagasan, materi pendidikan serta peserta didik itu sendiri (Ananda Hadi Elyas, 2018).

Komunikasi sebagai media pendidikan dilakukan dengan menggunakan media-media komunikasi seperti telepon, komputer, internet, e-mail dan sebagainya. Interaksi antara guru dan peserta didik tidak hanya dilakukan melalui hubungan tatap muka tetapi juga menggunakan media-media tersebut (Rosenberg, 2016).

Pendidikan online memungkinkan guru dan siswa untuk mengatur kecepatan belajar mereka sendiri, dan ada fleksibilitas tambahan dalam mengatur jadwal yang sesuai dengan agenda semua orang. Akibatnya, menggunakan platform pendidikan online memungkinkan keseimbangan kerja dan studi yang lebih baik, sehingga tidak perlu menyerah. Belajar online mengajarkan kita keterampilan manajemen waktu yang vital, yang membuat seseorang menemukan keseimbangan belajar dan kerja yang baik lebih mudah. Memiliki agenda bersama antara siswa dan guru juga dapat mendorong kedua belah pihak untuk menerima tanggung jawab baru.

Pada penelitian ini, peneliti menekankan pentingnya pemanfaatan e-learning untuk bidang pendidikan, hal ini juga dikemukakan oleh Kuryanti S.J bahwa kelebihan E-learning adalah memberikan fleksibilitas, interaktivitas, kecepatan, visualisasi melalui berbagai kelebihan dari masing-masing media E-learning memiliki banyak kelebihan yaitu (Kuryanti S.J, 2016):
1. Lebih mudah diserap, artinya menggunakan fasilitas multimedia berupa gambar, teks, animasi, suara, video.

2. Jauh lebih efektif dalam biaya, artinya tidak perlu instruktur, tidak perlu minimum audiensi, bisa dimana saja, bisa kapan saja, murah untuk diperbanyak.

3. Jauh lebih ringkas, artinya tidak banyak formalitas kelas, langsung pada pokok bahasan, mata pelajaran sesuai kebutuhan.

4. Tersedia $24 \mathrm{jam} / \mathrm{hari}-7 \mathrm{hari} /$ minggu, artinya penguaasaan materi tergantung pada semangat dan daya serap siswa, bisa dimonitor, bisa diuji dengan e-test.

Pentingnya penggunaan e-learning juga bisa terasa seperti kondisi saat ini, dimana suatu Negara dengan terpaksa harus menghentikan proses belajar mengajar secara langsung atau tatap muka dengan belajar mengajar secara daring (online). Semua pelajar baik itu sekolah dasar hingga mahasiswa harus melakukan proses belajar mengajar secara online. Bahkan sebagian besar pekerja juga melakukan pekerjaannya di rumah. Di era digital saat ini, belajar tanpa harus bertatap muka dengan tenaga pengajar sudah bukan menjadi masalah berat. Sebab, ada alternatif e-learning yang bisa dimanfaatkan di dunia pendidikan. E-learning atau electronic learning adalah sistem pembelajaran yang memanfaatkan perangkat komputer dan teknologi agar tujuan pembelajaran tercapai. Banyak sekali sebaran situs belajar online yang bisa dipilih sesuai kemampuan. Ada yang berbayar bahkan gratis. Bahkan, group chat pun bisa dikembangkan menjadi sarana e-learning. Beragam aplikasi untuk meeting juga turut direkomendasikan demi mempermudah interaksi pengajar dan peserta didik.

\section{KAJIAN LITERATUR}

\section{II.1 E-Learning}

E-learning dapat didefinisikan sebagai sebuah bentuk teknologi informasi yang diterapkan di bidang pendidikan dalam bentuk dunia maya. Penerapan elearning untuk pembelajaran online pada masa sekarang ini sangatlah mudah dengan memanfaatkan modul Learning Management System yang mudah untuk diinstalasi dan dikelola seperti Moodel. Hal ini juga dikemukakan oleh Wiwin bahwa Sistem dan 
aplikasi e-learning yang sering disebut dengan Learning Management System (LMS), yang merupakan sistem perangkat lunak yang memvirtualisasi proses belajar mengajar konvensional untuk administrasi, dokumentasi, laporan suatu program pelatihan, ruangan kelas dan peristiwa online, program e-learning, dan konten pelatihan, misalnya, segala fitur yang berhubungan dengan manajemen proses belajar mengajar seperti bagaimana manajemen kelas, pembuatan materi atau konten, forum diskusi, sistem penilaian, serta sistem ujian online yang semuanya terakses dengan internet (Wiwin Hartanto, 2017).

Pendidikan merupakan suatu proses yang mencakup tiga dimensi, individu, masyarakat atau komunitas nasional dari individu tersebut, dan seluruh kandungan realitas, baik material maupun spiritual yang memainkan peranan dalam menentukan sifat, nasib, bentuk manusia maupun masyarakat. Pendidikan lebih dari sekedar pengajaran, yang dapat dikatakan sebagai suatu proses transfer ilmu, transformasi nilai, dan pembentukan kepribadian dengan segala aspek yang dicakupnya. Dengan demikian pengajaran lebih berorientasi pada pembentukan spesialis atau bidang-bidang tertentu, oleh karena itu perhatian dan minatnya lebih bersifat teknis (Nurkholis, 2013).

Pemanfaatan e-learning tidak terhindar dari pemanfaatan teknologi pendukungnya yaitu internet. E-learning merujuk pada penggunaan teknologi internet untuk mengirimkan serangkaian solusi yang dapat meningkatkan pengetahuan dan keterampilan (Rosenberg, 2001). Hal ini senada dengan Cambell (2002), Kamarga (2002) yang intinya menekankan penggunaan internet dalam pendidikan sebagai hakekat elearning. Istilah "e" atau singkatan dari elektronik dalam e-learning digunakan sebagai istilah untuk segala teknologi yang digunakan untuk mendukung usaha-usaha pengajaran lewat teknologi elektronik internet (Onno W. Purbo, 2002). Internet, Intranet, satelit, tape audio/video, TV interaktif dan CD-ROM adalah sebagian dari media elektronik yang digunakan Pengajaran boleh disampaikan secara 'synchronously' (pada waktu yang sama) ataupun 'asynchronously' (pada waktu yang berbeda). Materi pengajaran dan pembelajaran yang disampaikan melalui media ini mempunyai teks, grafik, animasi, simulasi, audio dan video. Ia juga harus menyediakan kemudahan untuk 'discussion group' dengan bantuan profesional dalam bidangnya (Numiek Sulistyo Hanum, 2013).

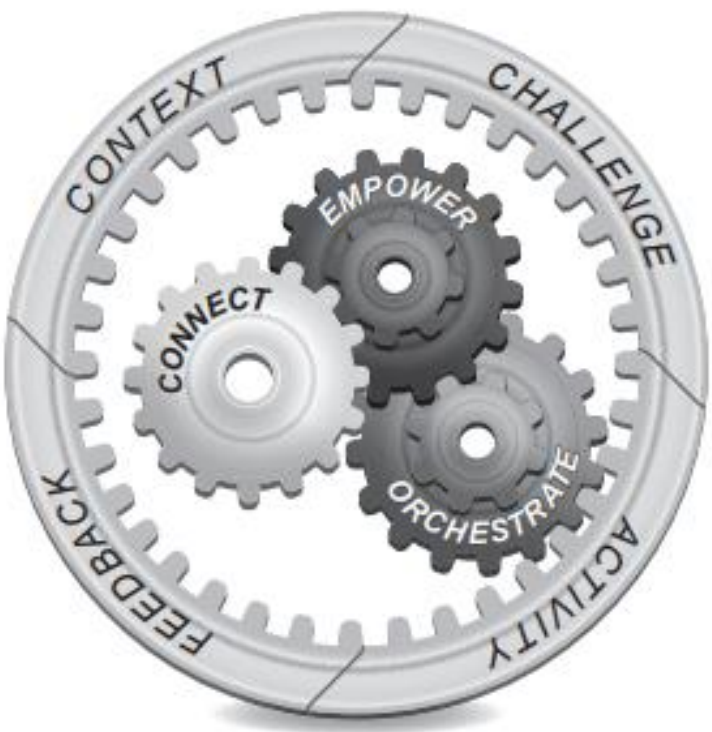

Gambar 1. CEO (Connect, Empower, and Orchestrate) dan CCAF (Context, Challenge, Activity, and Feedback)

Pengalaman belajar dinyatakan sukses jika memanfaatkan teknologi e-learning sebagai media pembelajaran dalam penyampaian materi atau sebaliknya. Connect yaitu terhubung dengan peserta didik; Empower yaitu memberdayakan mereka untuk mengeksplorasi, bereksperimen, dan bereaksi; Orchestrate yaitu mengatur lingkungan belajar dengan sedemikian rupa sehingga dapat memberikan umpan balik yang kritis, bantuan, dan bimbingan (Allen, 2016).

Untuk mencapai tujuan instruksional ada empat komponen penting, terintegrasi dan saling terkait seperti teka - teki jigsaw, yaitu (Allen, 2016):

- Context yaitu merupakan kerangka kerja dan kondisi.

- Challenge merupakan sebuah stimulus untuk bertindak sesuai konteksnya.

- Activity yaitu espons fisik terhadap tantangan.

- Feedback merupakan refleksi dari keefektifan tindakan pelajar.

Gambar 2 mengilustrasikan komponen permainan strategis di mana pemain membuat keputusan untuk mencapai tujuan dan menerima penghargaan. Konten tersebut dimasukkan ke dalam game itu sendiri dan terdiri dari tiga bagian utama, yaitu (Allen, 2016): 
- Rules (Aturan Main dan Aturan Hasil)

- $\quad$ Player Strategies (memutuskan tindakan apa yang akan diambil dan kapan)

- CCAF (konteks, tantangan, aktivitas, dan umpan balik).

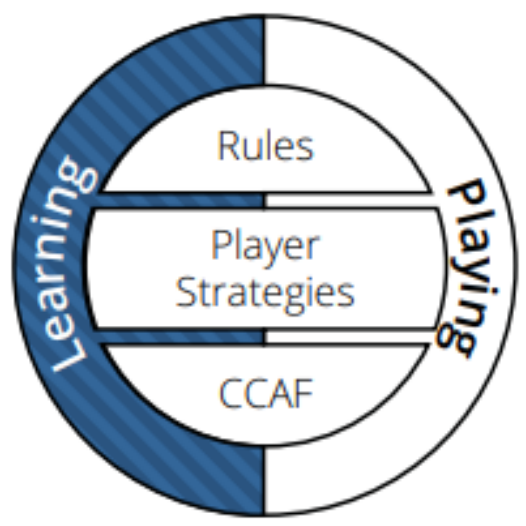

\section{Gambar 2. Konten Pembelajaran dalam game strategi}

\section{II.2 Metode Penelitian}

Pada penelitian ini, penulis menggunakan model waterfall yang telah dikembangkan oleh sommerville. Tetapi, penulis mengembangkan model waterfall tersebut sesuai dengan kebutuhan penelitian. Adapun model waterfall yang dikembangkan oleh penulis dapat dilihat pada Gambar 3.

Tahap persiapan merupakan proses pengumpulan kebutuhan secara lengkap, kemudian dianalisis dan didefinisikan masalahnya serta kebutuhan yang diperlukan dalam proses penelitian. Adapaun yang dilakukan oleh peneliti dalam tahap ini yaitu rumusan masalah dan tujuan penelitian, studi literatur dan pengumpulan data.

Tahap analisis dan perancangan, tahap ini merupakan tahap untuk melakukan analisis terhadap sistem yang sedang berjalan dan sistem yang akan dibangun serta melakukan design terhadap kebutuhan yang sebelumnya telah dikumpulkan secara lengkap. Adapun proses yang dilakukan oleh peneliti pada tahap ini yaitu analisis sistem, analisis kebutuhan dan perancangan.

Tahap implementasi dan pengujian, tahap ini merupakan proses yang berfungsi untuk menterjemahkan desain database, prototype dan program ke dalam kode dengan menggunakan bahasa pemrograman yang telah ditentukan dan kemudian dilakukan pengujian terhadap unit tersebut. Peneliti melakukan proses penelitian pada tahap ini dibagi menjadi dua bagian, yaitu implementasi, pengujian black box dan pengujian aspek pengguna.

Tahap pelaporan merupakan proses atau tahap terakhir yang dilakukan oleh peneliti dalam metode penelitian ini. Software dan modul yang sudah diintergrasikan menjadi satu sistem dengan e-learning kemudian dilakukan proses installasi dan mulai digunakan. Kemudian hasil dari sistem tersebut diimplementasikan, dilakukan analisis dan dibuatkan laporannya sebagai hasil dari penelitian.

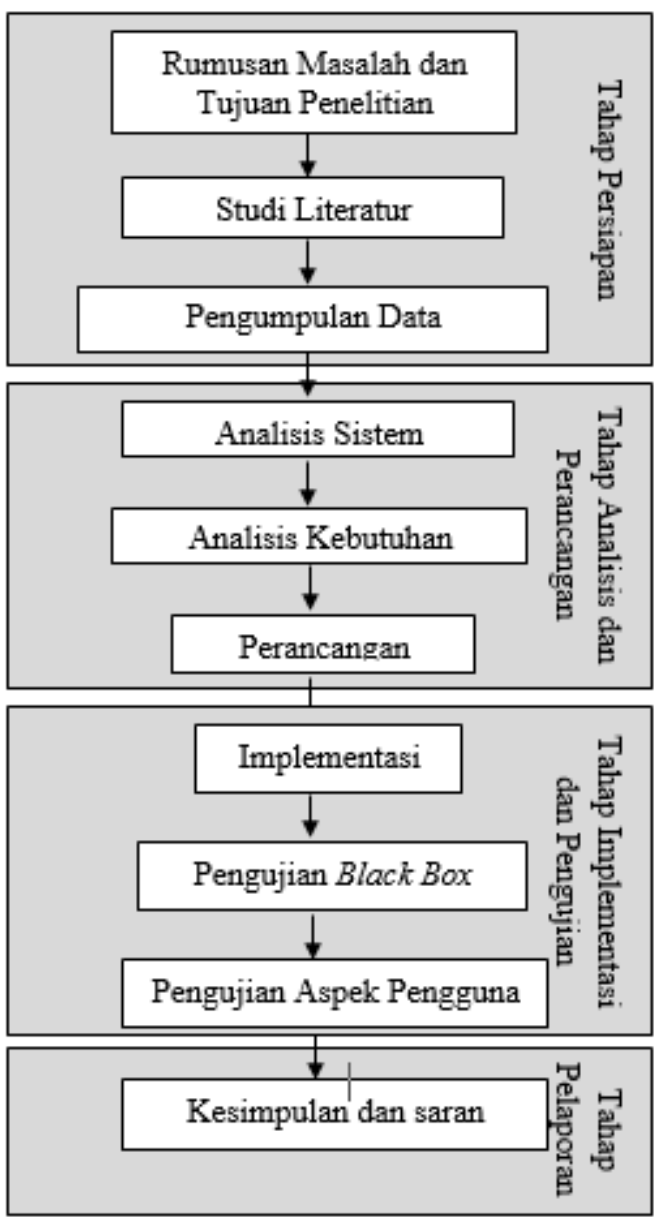

Gambar 3. Metodologi Penelitian 


\section{ANALISIS DAN PERANCANGAN}

\section{III.1 Analisis Sistem}

Analisis merupakan penelaahan atau penelitian dengan melakukan suatu percobaan yang menghasilkan kesimpulan dari penguraian suatu sistem informasi yang utuh kedalam bagian-bagian komponennya dengan maksud untuk mengidentifikasi dan mengevaluasi segala permasalahan yang timbul.

Analisis kebutuhan yang dimaksud disini berupa analisis Bizagi Modeler mengenai sistem yang akan dibangun. Adapun Bizagi Modeler yang akan dibangun yaitu seperti pada Gambar 4 .

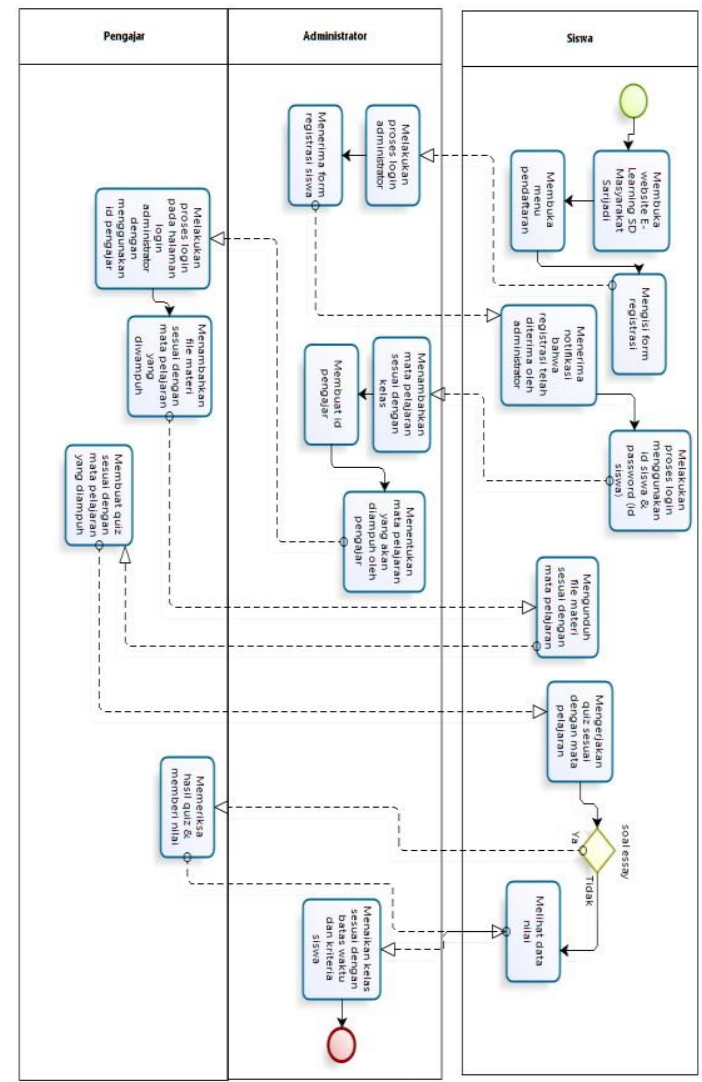

\section{Gambar 4. Bizagi Modeler sistem yang akan dibangun.}

Kebutuhan fungsional adalah jenis kebutuhan yang berisi proses - proses yang dilakukan oleh sistem dan informasi - informasi yang dihasilkan oleh sistem. Adapun proses yang dilakukan sistem dan informasi yang dihasilkan oleh sistem adalah:
1. Siswa diharuskan untuk mendaftarkan akun sebelum melakukan proses login;

2. Siswa dapat melakukan login menggunakan NIS dan password yang telah dibuat;

3. Siswa dapat mengunduh materi yang sudah tersedia di sistem e-learning;

4. Siswa dapat melihat daftar mata pelajaran yang tersedia;

5. Siswa dapat mengerjakan latihan tugas atau quiz yang disediakan oleh pengajar;

6. Siswa dapat mencetak hasil nilai dari tugas atau quiz yang sudah di kerjakan;

7. Siswa dapat mengedit akun siswa jikalau ada biodata siswa yang ingin diubah;

8. Siswa dapat melakukan pembelajaran yang menggunakan konsep learning games.

9. Siswa dapat memberikan feedback kepada pengajar;

10. Admin dapat mengatur akun siswa;

11. Admin dapat mengatur akun pengajar;

12. Admin dapat mengatur mata pelajaran yang akan dipelajari;

13. Admin dapat menambahkan modul kedalam elearning;

14. Pengajar dapat memberikan file materi mata pelajaran berbasis game;

15. Pengajar dapat memberikan feedback kepada siswa;

16. Pengajar dapat menambahkan tugas dan quiz.

Kebutuhan nonfungsional merupakan kebutuhan yang berisi property yang dimiliki oleh sistem. Kebutuhan nonfungsional sistem ini yaitu:

1. Kinerja

a. Menambah metode pembelajaran yang lebih interaktif yaitu dengan adanya fasilitas feedback, sehingga antara siswa dengan pengajar dapat saling berinteraksi;

b. Pembelajaran berbasis game yang dapat meningkatkan motivasi siswa dan siswi di lingkungan Sekolah Dasar untuk belajar dengan menyenangkan;

c. Melatih kecerdasan siswa dan siswi di lingkungan sekolah dasar dengan pemberian tugas atau quiz.

2. Keamanan 
Keamanan yang diimplementasikan pada sistem berisi keamanan aplikasi, keamanan data. Adapun kebutuhan yang mencakup dengan keamanan antara lain:

a. Pengguna (siswa dan pengajar) diberikan hak akses yang berbeda - beda;

b. Setiap siswa meliliki NIS yang berbeda.

\section{III.2 Perancangan}

\section{Use Case Diagram}

Use case diagram merupakan konstruksi untuk mendeskripsikan hubungan-hubungan yang terjadi antar aktor dengan aktivitas yang terdapat pada sistem. Adapun Use Case Diagram pada aplikasi elearning seperti pada Gambar 5 dan 6.

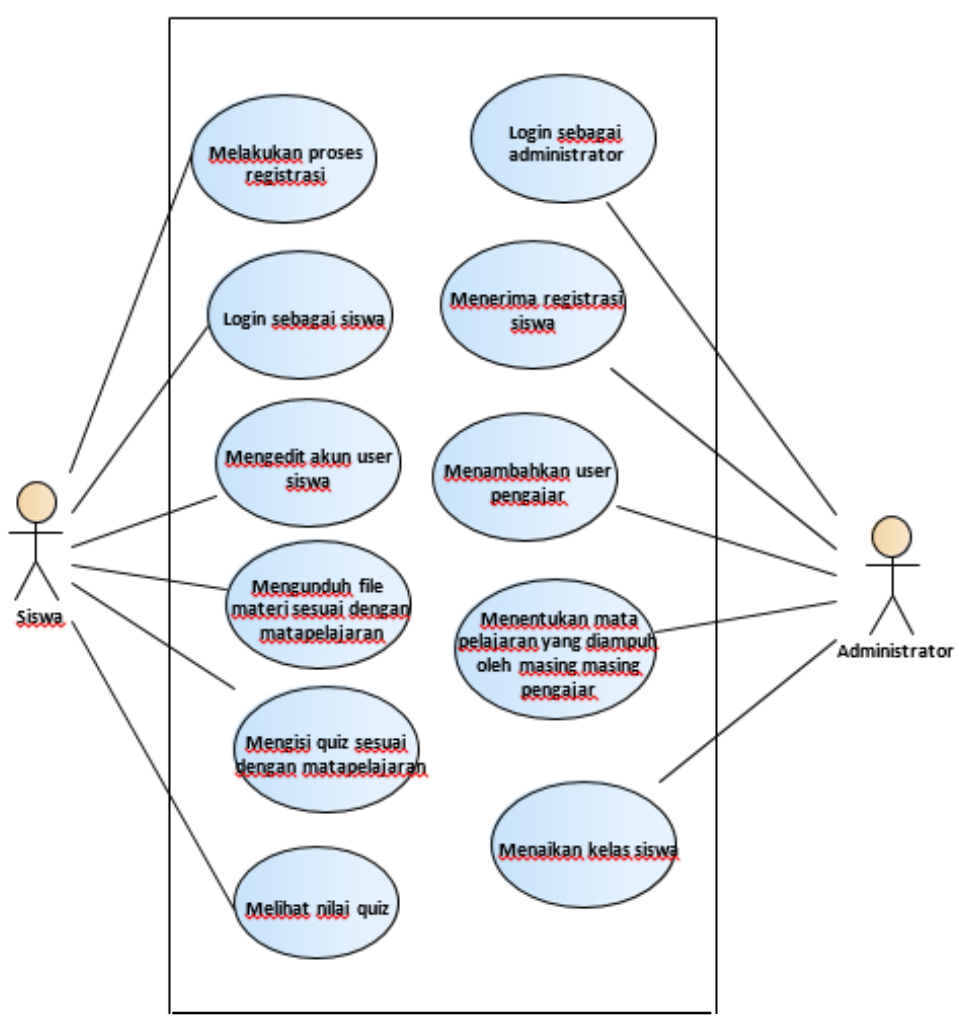

Gambar 5. Use case diagram actor siswa \& administrator

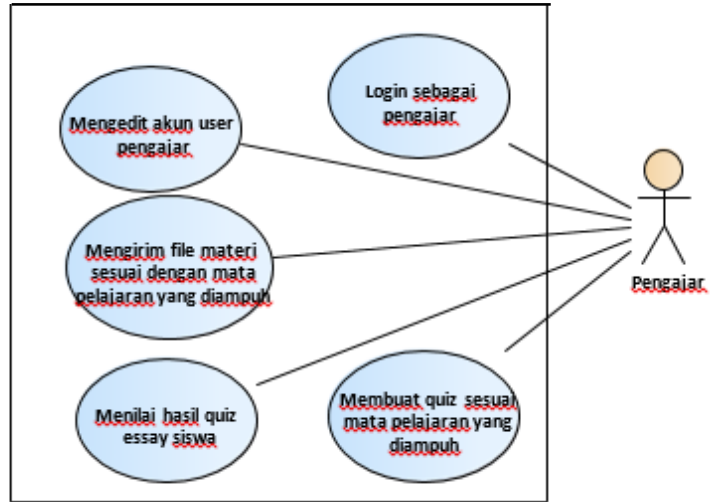

Gambar 6. Use case diagram actor pengajar

2. Deployment Diagram

Diagram ini memperlihatkan konfigurasi saat aplikasi dijalankan (run-time). Memuat simpulsimpul beserta komponen-komponen yang ada di dalamnya. Diagram deployment berhubungan erat dengan diagram komponen dimana diagram ini memuat satu atau lebih komponen-komponen. Diagram ini sangat berguna saat aplikasi kita berlaku sebagai aplikasi yang dijalankan pada banyak mesin (distributed computing).

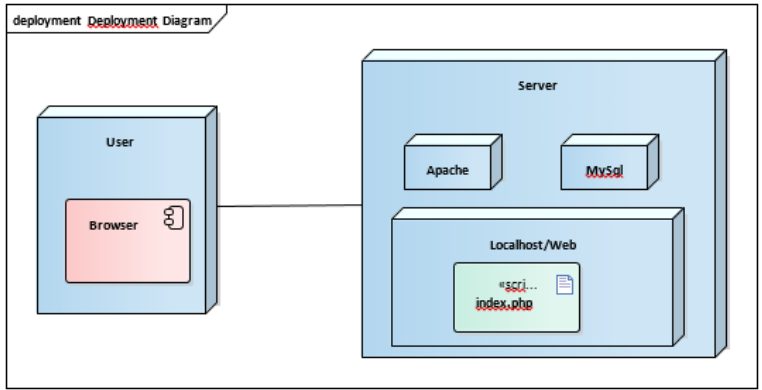

Gambar 7. Deployment Diagram Sistem ELearning

3. Tampilan Login

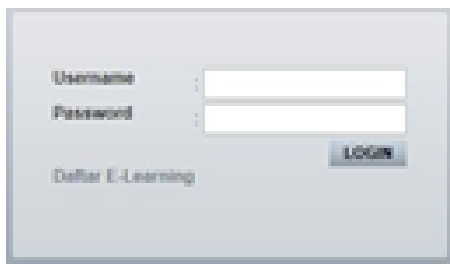

Gambar 8. Tampilan Login

Halaman index ini merupakan halaman awal yang akan tampil ketika user memasukan alamat website e-learning. Halaman ini berisi form login 
siswa dan tombol "Daftar" yang akan menuju ke halaman pendaftaran.

4. Tampilan Antarmuka Menu Siswa

Halaman ini berisi daftar menu untuk siswa sekolah dasar, yaitu menu utama yang di dalamnya terdapat menu: Kelas Anda, Mata Pelajaran, Materi, Tugas/Quiz, dan Nilai, serta terdapat informasi Account yang bisa mengecek dari profil siswa tersebut, dalam menu Account terdapat menu: Edit Profil, Edit Username dan Password.

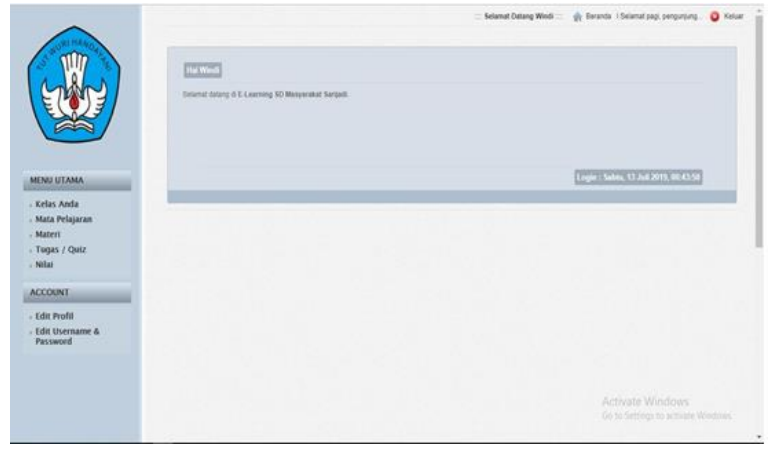

Gambar 9. Tampilan Antarmuka User Siswa

5. Tampilan Antarmuka User Administrator

Halaman ini berisi menu administrator yang didalamnya terdapat menu utama dan informasi user administrator.

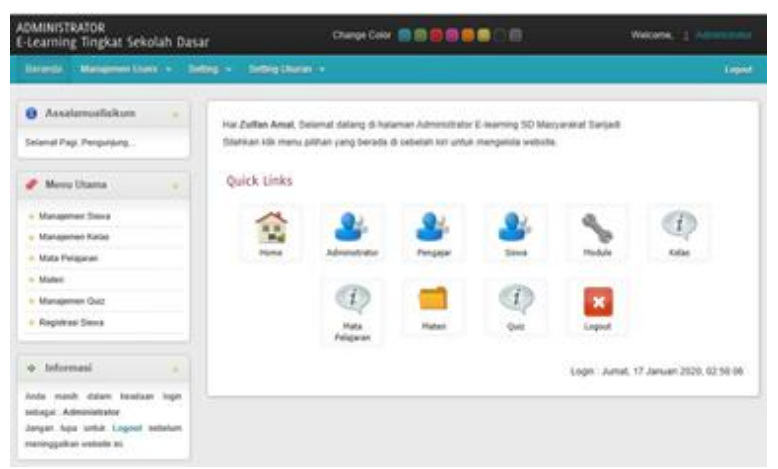

Gambar 10. Tampilan Antarmuka User Administrator

6. Pembelajaran Game Board

Pada Gambar 11 merupakan contoh pembelajaran berbasis game dimana pelajar diminta untuk memasukkna makanan mentah di atas ke dalam pemanggangan dan wajan, kemudian menunggu sampai matang dengan benar, lalu menyimpannya ke piring di bawah dan mencocokkan tiket pesanan dengan kode warna di sebelah kiri.

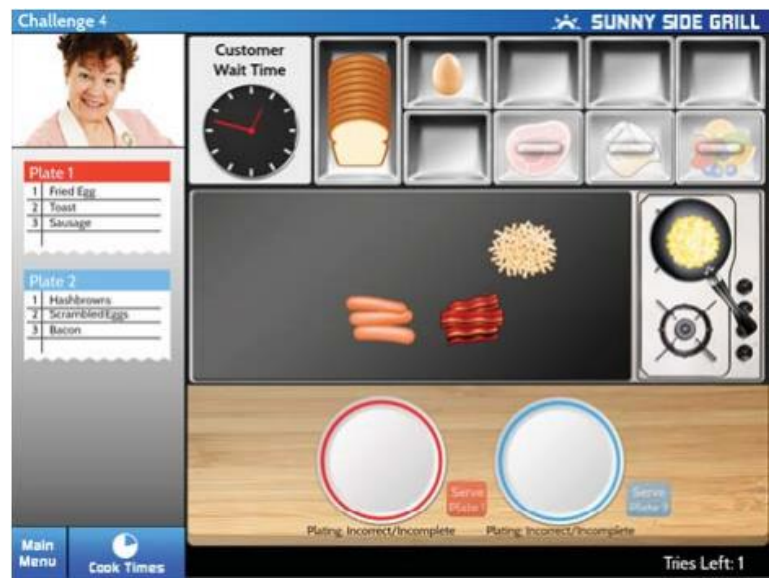

Gambar 11 Pembelajaran berbasis Game

\section{KESIMPULAN DAN SARAN}

Berdasarkan dari penelitian yang telah dilakukan, maka dapat disimpulkan sebagai berikut, yaitu:

1. Sistem yang dibangun yaitu sistem E-learning sebagai media pembelajaran untuk anak-anak tingkat Sekolah Dasar.

2. Memberikan kesempatan kepada anak - anak tingkat Sekolah Dasar untuk dapat mengakses materi, mata pelajaran, soal latihan sehingga dapat meningkatkan partisipasi siswa dalam pembelajaran.

3. Sistem yang dibangun dapat menyediakan materi pembelajaran dan saoal latihan dengan metode learning games sehingga pembelajaran menjadi lebih interaktif dan menyenangkan.

Adapun saran untuk perbaikan penelitian berikutnya yaitu:

1. Perlu dikembangkan sistem e-learning yang dapat memfasilitasi pengajar dalam membuat learning games.

2. Perlu dikembangkan sistem m-Learning (Mobile Learning) untuk kegiatan pembelajaran di tingkat Sekolah Dasar. 


\section{REFERENSI}

Kusmana, A. (2011). E-learning dalam pembelajaran. Lentera Pendidikan, 14 (1), 35-51.

Soepeno, B. (2014). Penggunaan Aplikasi CMS Wordpress Untuk Merancang Website Sebagai Media Promosi pada Maroon Wedding Malang. JURNAL AKUNTANSI, EKONOMI dan MANAJEMEN BISNIS| eISSN: 2548-9836, 2(1), 63-69.

Enterprise, J. (2016). Pengenalan HTML dan CSS. Elex Media Komputindo.

Koesheryatin, T. S. (2014). Aplikasi Internet Menggunakan HTML, CSS, dan JavaScript. Elex Media Komputindo.

Sianipar, R. H. (2016). Pemrograman Database Menggunakan MySQL (Vol. 1). Penerbit ANDI.

Aryanto. (2016). Pengolahan Database MySQL, Yogyakarta : Deepublish.

Batubara, F. A. (2015). Perancangan Website Pada PT. Ratu Enim Palembang. JURNAL ILMU PENGETAHUAN DAN TEKNOLOGI TERAPAN" REINTEK"(REKAYASA INOVASI TEKNOLOGI), 7(1).
Muslihudin, M. (2016). Analisis Dan Perancangan Sistem Informasi Menggunakan Model Terstruktur Dan UML. Penerbit Andi.

Suharyanto, S., \& Mailangkay, A. (2016). Penerapan E-learning sebagai Alat Bantu Mengajar dalam Dunia Pendidikan. Jurnal Ilmiah Widya, 3(4), 17-21.

Falahudin, I. (2014). Pemanfaatan media dalam pembelajaran. Jurnal Lingkar Widyaiswara, 1(4), 104-117.

Al-Bahra Bin Ldjamudin. (2015). Analisis \& Desain Sistem Informasi. Yogyakarta : Graha Ilmu.

Pressman, Roger S. (2017). Rekayasa Perangkat Lunak : pendekatan praktisi (Buku1). Black Box Testing. Yogyakarta : Andi.

Allen, M. W. (2016). Michael Allen's guide to elearning: Building interactive, fun, and effective learning programs for any company. John Wiley \& Sons. 